\title{
PHYTOSOCIOLOGY AND STRUCTURAL CHARACTERIZATION OF WOODY REGENERATION FROM A REFORESTATION WITH NATIVE SPECIES IN SOUTHEASTERN BRAZIL ${ }^{1}$
}

\author{
Michel Anderson Almeida Colmanetti ${ }^{2 *}$, Luiz Mauro Barbosa ${ }^{3}$, Regina Tomoko Shirasuna ${ }^{3}$ and Hilton \\ Thadeu Zarate do Couto ${ }^{4}$
}

\footnotetext{
${ }^{1}$ Received on 21.05.2014 accepted for publication on 09.12.2015.

2 Instituto de Botânica, Mestrado em Biodiversidade Vegetal e Meio Ambiente, São Paulo, SP - Brasil. E-mail: $<$ michelcolmanetti@gmail.com>.

${ }^{3}$ Coordenação Especial para Restauração Ecológica de Áreas Degradadas, Instituto de Botância, São Paulo, SP - Brasil. E-mail: <lmbarbosa.ibt@gmail.com> and <regina.shirasuna@hotmail.com>.

${ }^{4}$ Universidade de São Paulo, Departamento de Ciências Florestais, Escola Superior de Agricultura Luiz de Queiroz, Piracicaba, SP - Brasil. E-mail:<htzcouto@usp.br>.

${ }^{*}$ Corresponding author.
}

\begin{abstract}
In Brazil, specifically in São Paulo State, there are guidelines based on the high diversity of tropical forests that instructs the restoration projects in the state (current SMA 32/2014). The main goal of this study was verify the importance and effectiveness of the high diversity of arboreal species originated from a reforestation, and its influence in a woody regenerating composition. We developed a phytosociologic study in a woody regenerating stratum of a nine year old reforestation at a Private Reserve of Natural Heritage (RPPN), in Mogi-Guaçu, São Paulo State. All specimens with height $\geq 30 \mathrm{~cm}$ and Diameter at Breast Height $(\mathrm{DBH})<5 \mathrm{~cm}$ were evaluated. The woody regenerating diversity was smaller than the overstory diversity and the species composition was similar to the overstory. The Simpson index (1-D) was 0.85 , Shannon index $\left(\mathrm{H}^{\prime}\right)$ was 2.46 and the Pielou index (J') was 0.60 . The zoochoric dispersion syndrome was major among the species. Our results suggest that the use of high diversity of native seedlings in a reforestation leads to high diversity of species in woody regeneration stratum, after one decade of planting.
\end{abstract}

Keywords: Diversity of seedlings; Zoochoric dispersion; Atlantic Forest restoration

\section{FITOSSOCIOLOGIA E CARACTERIZAÇÃO ESTRUTURAL DO ESTRATO REGENERANTE DE UM REFLORESTAMENTO COM ESPÉCIES NATIVAS NO SUDESTE DO BRASIL}

\begin{abstract}
RESUMO - No Brasil, especificamente no Estado de São Paulo, existem resoluções que se baseiam na alta diversidade das florestas tropicais, e que instruem os projetos de restauração no Estado (Atual SMA 32/2014). O principal objetivo desse estudo foi verificar a importância e sucesso do uso da alta diversidade de espécies arbóreas oriundas de um reflorestamento e sua influência no estrato regenerante. Foi realizado um estudo fitossociológico de um estrato regenerante de um reflorestamento em uma Reserva Particular do Patrimônio Natural (RPPN), com nove anos de idade, em Mogi-Guaçu, SP. Foram avaliados todos os espécimes com altura $\geq 30 \mathrm{~cm}$ e Diâmetro à Altura do Peito $(D A P)<5 \mathrm{~cm}$. A diversidade do estrato regenerante foi menor que o estrato arbóreo, com base em um estudo prévio. A composição de espécies do estrato regenerante foi similar à composição do estrato arbóreo. O índice de Simpson (1-D) foi 0.85, de Shannon (H') foi 2.46 e de Pielou $(J$ ') foi 0.60. A maioria das espécies amostradas eram zoocóricas. Com base nos resultados, acredita-se que o uso de alta diversidade de mudas nativas em um reflorestamento, no momento do plantio, leva a uma alta diversidade de espécies no estrato regenerante, após uma década.
\end{abstract}

Palavras chave: Diversidade de mudas; Dispersão zoocórica; Restauração da Mata Atlântica. 


\section{INTRODUCTION}

The Brazilian Atlantic Forest has one of the most important biodiversity in the world, but concerning its historical degradation, habitat fragmentation and the endemic threatened species, this biome has been considered an important "hot spot" (MYERS et al., 2000). As a result of this process, there is only 11 to $16 \%$ (16,377,472 ha) from the original area (RIBEIRO et al., 2009). And because of this scenario, some procedures are required to the conservation of this biome and its biodiversity, as well as the conservation of the remnants and the restoration of the degraded areas (RODRIGUES et al. (2009a).

Regarding to restoration of degraded areas in Brazil, specifically in São Paulo State, there is a piece of legislation -SMA32/2014(SÃO PAULO, 2014), which guides projects of ecological restoration in the State. These guides are based on the high diversity of tropical forests in the country, and their practice has been broadly discussed by many authors (ARONSON et al., 2011; CALMON et al., 2011; RODRIGUES et al., 2011), and confronted by others (BRANCALION et al., 2010; DURIGAN et al., 2010).

Although it will be able to evaluate the success or failure of these guidelines over the last few decades, it is important to verify and assess the initial development of the reforestation implanted, based on these guidelines. In order to do so, it's necessary to evaluate the reforestation by using indicators according to the age of each reforestation, allowing to reach conclusions whether the reforestations have the evidence of sustainability or not over the time or if they demand new interventions (RODRIGUES et al., 2009b).

Based on the assessment of the woody regeneration is possible to verify the influence of the canopy that grew from seedlings planted, favoring the habitat colonized by new species (GUILHERME, 2000; MELO; DURIGAN, 2007). This assessment allows the analysis of the success of the seedlings planted and new species which are colonizing the reforestation, showing process such as floral and reproductive biology have been reestablished (BARBOSA; PIZO, 2006).

The objective of this study was to verify the woody regenerating species composition of a RPPN reforestation, and the effectiveness and influence of the canopy formed by a high diversity reforestation of native species on its composition.

Revista Árvore, Viçosa-MG, v.40, n.2, p.209-218, 2016

\section{MATERIALAND METHODS}

\subsection{Study site}

This study was conducted from January 2011 to December 2011 in the Private Reserve of Natural Heritage (RPPN), in the city of Mogi-Guaçu, São Paulo State, Southeast Brazil (22²2'28"S, 4658'31"W). The reforestation was implanted with 100 native species, and density of 1,333 seedlings ha-1, in total area of 240 ha. This RPPN and is currently nine years old. Since implantation, the RPPN has been used on many studies of different parameters of vegetation and local fauna (MANDETTA, 2007; SILVEIRA et al., 2011; COLMANETTI; BARBOSA, 2013; COLMANETTI et al. 2015; TREVELIN et al., 2013).

The considerable remnants are more than $10 \mathrm{~km}$ from the RPPN, but there are a few riparian forests and other reforestation nearby the RPPN. Over the past years, this land has been mostly used for livestock and agriculture, including citrus, coffee and sugarcane until 1995, and Eucalyptus sp. plantation from 1995 until 2001. In 2002, the area was destined to reforestation with seedlings of native species, and 40 permanent plots ( $36 \times 62.5 \mathrm{~m}$ ) were installed, and 20 among them were selected to this study. For detailed information on the restoration project, see Colmanetti (2013).

Currently, the RPPN is inserted in a mosaic of land cover, including seasonal semideciduous forest remnants, eucalyptus plantations, other anthropogenic land cover and heterogeneous reforested areas. Remnants of Cerrado biome (Neotropical Savana) are also found surrounding the RPPN. The region's climate is Cwa (dry winter and moist summer) according to Köppen (1948). Annual precipitation is $1,066 \mathrm{~mm}$, and average temperature is $21.4^{\circ} \mathrm{C}$. The soil of the site study is classified as Latossol and Argisol.

\subsection{Vegetation structure and composition analyses}

The phytosociology study of the woody regenerating stratum was developed in 20 subplots $(12.5 \times 18 \mathrm{~m})$, located in 20 permanent plots $(36 \mathrm{x}$ $62.5 \mathrm{~m})$. The heights of all the specimens with height $\geq 30 \mathrm{~cm}$ and Diameter at Breast Height $(\mathrm{DBH})<5 \mathrm{~cm}$ were evaluated. The species were identified and updated according to Brazilian Species Flora List by consulting the site (www.floradobrasil.jbrj.gov.br) and Missouri Botanical Garden consulting the site 
(www.tropicos.org). and The families were organized according to Angiosperm Phylogeny Group (APG III, 2009).

The successional groups were classified as pioneers and non-pioneers, and the dispersal syndromes were classified as zoochoric, anemochoric and autochoric species according to species list established by the guideline SMA number 21/2001 (current 32/2014).

\subsection{Data analysis}

The Relative Frequency (R.F.), Relative Abundance (R.A.) and Cover Value (CV) were calculated according to Mueller-Dombois e Ellenberg (1974). This study applies the height of the woody regenerating specimens to calculate the Relative Dominance (R.D.). The use of the average height of each species divided by the average height of all species was proposed, as presented below:

$$
\sum_{\mathrm{i}=1}^{\mathrm{s}} \text { AHi } \mathrm{R} . \mathrm{D} .=\text { Relative Dominance of "i" }=100 \times \mathrm{AHi} /
$$

"AHi" is Average Height of each specie " $i$ ". It was calculated the Importance Value (IV) by summing Relative Frequency, Relative Abundance and Relative Dominance.

The diversity was calculated by Shannon index (H'), in natural logarithm, and Simpson index (1-D) (SIMPSON, 1949; MAGURRAN, 2004). The equitability (J') was calculated from Shannon index in relation to the maximum diversity possible according to Pielou (1975).

The Jaccard index (MAGURRAN, 2004) was calculated, among the woody regenerating and overstory species composition. The composition of overstory of the same area was obtained from Colmanetti e Barbosa (2013). The Jaccard index was calculated by using the PAST program (HAMMER; HARPER; RYAN, 2001). The diversity indexes and phytosociologic values were calculated by using SAS 9.2 System for Windows (SAS INSTITUTE, 2007).

\section{RESULTS}

We evaluated 3,591 specimens (7,980 specimens.ha $\left.{ }^{-1}\right)$, and the floristic composition of the woody regenerating stratum was constituted by 62 species, 55 genera and 29 families. A larger number of species was autochthonous, actually, 44 species (71\%), and just
$13(20.9 \%)$ were considered as allochthonous species. The majority of species was zoochoric. The woody regenerating species composition was very similar to the overstory of the same area, actually there were 43 species in common (COLMANETTI; BARBOSA, 2013). The Jaccard index for overstory and woody regenerating strata was 0.46 . The presence of five species that occur in Cerrado sensu lato (Neotropical Savana) was notable: Xylopia aromatica, Erythroxylum campestre, Pera glabrata, Myrsine coriacea and Zanthoxylum riedelianum.

The Simpson index (1-D) was 0.85 , Shannon index $\left(\mathrm{H}^{\prime}\right)$ was 2.46 and the Pielou index (J') was 0.60 , The most abundant species were Myrsine umbellata, Senegalia polyphylla, Mimosa bimucronata, Schinus terebinthifolius, Triplaris americana and Parapiptadenia rigida (Table 1). Most of these species were very frequent, excepted $T$. americana and $P$. rigida, which had a restrict occurrence to few subplots.

The pioneer species were the most common (41.9\%), following by non-pioneers species (37.1\%), nonclassified species (11.3\%) and exotics species (9.7\%). It was observed the predominance of the pioneer specimens, $84.3 \%$, influenced by abundance of some species, such as: Myrsine umbellata, Senegalia polyphylla, Schinus terebinthifolius, Mimosa bimucronata, Parapiptadenia rigida and Triplaris americana.

The zoochoric species were predominant (42.0\%), following by anemochoric (29.0\%) and autochoric species (17.7\%) It was found 13 allochthonous species on RPPN wood regenerating, and nine were zoochoric species: Xylopia aromatica, Erythroxylum campestre, Alchornea glandulosa, Pera glabrata, Melia azedarach, Myrsine coriacea, Eriobotrya japonica, Coffea arabica and Zanthoxylum riedelianum.

About $95 \%$ of specimens evaluated have until $2 \mathrm{~m}$ of height, and this size class has higher species diversity. The specimens higher than 3 meters were majority composed by pioneer species: Alchornea glandulosa, Aloysia virgata, Croton urucurana, Croton floribundus, Mimosa bimucronata, Senna multijuga, Myrsine umbellata, Senegalia polyphylla, Tecoma stans, Mimosa caesalpiniifolia, and one non-pioneer species: Nectandra megapotamica, and the most abundant species of them were C. floribundus and T. stans.

Revista Árvore, Viçosa-MG, v.40, n.2, p.209-218, 2016

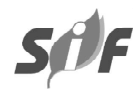


Table 1 - Phytossociologic values of woody regenerating composition of RPPN "Parque São Marcelo", Mogi-Guaçu, São Paulo State, Brazil. SG - Successional Group; DS - Dispersion Syndrome; RF - Relative Frequency; RD - Relative Dominance; RA - Relative Abundance; CV - Cover Value; IV - Importance Value; P - Pioneer; NP - Non-Pioneer; E - Exotic; NC - Not Classified; An - Anemochoric; Au - Autochoric; Z - Zoochoric; Aut - Autochthonous; Al - Allochthonous.

Tabela 1 - Valores fitossociológicos da composição do estrato regenerante da RPPN "Parque São Marcelo”, Mogi-Guaçu, São Paulo/Brasil. SG - Grupo Sucessional; DS-Síndrome de Dispersão; RF-Frequência Relativa; RD-Densidade Relativa; RA - Abundância Relativa; CV - Valor de Cobertura; IV - Valor de Importância; P - Pioneira; NP -Não-Pioneira; E-Exótica; NC - Não Classificado; An - Anemocórica; Au - Autocórica; Z - Zoocórica; Aut - Autóctone; Al - Alóctone.

\begin{tabular}{|c|c|c|c|c|c|c|c|c|c|}
\hline Species & Families & SG & DS & Origin & $\mathrm{RF}$ & $\mathrm{RD}$ & RA & $\mathrm{CV}$ & IV \\
\hline Myrsine umbellata Mart. & Myrsinaceae & $\mathrm{P}$ & $\mathrm{Z}$ & Aut & 7.48 & 1.19 & 25.56 & 26.75 & 34.23 \\
\hline $\begin{array}{l}\text { Senegalia polyphylla (DC.) } \\
\text { Britton \& Rose }\end{array}$ & Fabaceae & $\mathrm{P}$ & $\mathrm{Au}$ & Aut & 6.3 & 1.42 & 24.17 & 25.59 & 31.89 \\
\hline Mimosa bimucronata (DC.) Kuntze & Fabaceae & $\mathrm{P}$ & $\mathrm{Au}$ & Aut & 2.36 & 1.51 & 9.08 & 10.59 & 12.95 \\
\hline Schinus terebinthifolius Raddi & Anacardiaceae & $\mathrm{P}$ & $\mathrm{Z}$ & Aut & 4.33 & 1.12 & 7.44 & 8.55 & 12.88 \\
\hline Tecoma stans (L.) Juss. ex Kunth* & Fabaceae & $\mathrm{E}$ & An & Al & 3.15 & 3.92 & 1.89 & 5.82 & 8.97 \\
\hline Croton floribundus Spreng. & Euphorbiaceae & $\mathrm{P}$ & $\mathrm{Au}$ & Aut & 3.94 & 2.33 & 2.65 & 4.97 & 8.91 \\
\hline $\begin{array}{l}\text { Parapiptadenia rigida (Benth.) } \\
\text { Brenan }\end{array}$ & Fabaceae & NP & $\mathrm{Au}$ & Aut & 0.39 & 1.12 & 7.13 & 8.24 & 8.64 \\
\hline Rhamnidium elaeocarpum Reissek & Rhamnaceae & NP & $\mathrm{Z}$ & Aut & 5.51 & 1.34 & 1.7 & 3.03 & 8.55 \\
\hline $\begin{array}{l}\text { Inga vera subsp. affinis (DC.) } \\
\text { T.D.Penn. }\end{array}$ & Fabaceae & $\mathrm{P}$ & $\mathrm{Z}$ & Aut & 5.12 & 1.72 & 1.62 & 3.33 & 8.45 \\
\hline Triplaris americana $\mathrm{L}$. & Polygonaceae & $\mathrm{P}$ & An & Aut & 1.97 & 0.92 & 5.35 & 6.26 & 8.23 \\
\hline Aloysia virgata (Ruiz \& Pav.) Juss. & Verbenaceae & $\mathrm{P}$ & An & Aut & 3.94 & 2.67 & 0.95 & 3.62 & 7.56 \\
\hline $\begin{array}{l}\text { Alchornea glandulosa Poepp. } \\
\text { \& Endl. }\end{array}$ & Euphorbiaceae & $P$ & $\mathrm{Z}$ & $\mathrm{A} 1$ & 3.54 & 2.27 & 0.86 & 3.14 & 6.68 \\
\hline Bauhinia forficata Link & Fabaceae & $\mathrm{P}$ & $\mathrm{Au}$ & Aut & 3.94 & 1.48 & 1.17 & 2.65 & 6.59 \\
\hline Eugenia uniflora $\mathrm{L}$ & Myrtaceae & NP & $\mathrm{Z}$ & Aut & 3.15 & 2.16 & 0.31 & 2.46 & 5.61 \\
\hline $\begin{array}{l}\text { Gochnatia polymorpha (Less.) } \\
\text { Cabrera }\end{array}$ & Asteraceae & $\mathrm{P}$ & An & Aut & 2.36 & 1.34 & 1.53 & 2.88 & 5.24 \\
\hline Mimosa caesalpiniifolia Benth.* & Fabaceae & $\mathrm{E}$ & $\mathrm{Au}$ & $\mathrm{Al}$ & 0.79 & 3.75 & 0.53 & 4.28 & 5.06 \\
\hline Psidium guajava L.* & Myrtaceae & $\mathrm{E}$ & $\mathrm{Z}$ & Aut & 3.15 & 1.21 & 0.33 & 1.55 & 4.7 \\
\hline $\begin{array}{l}\text { Senna multijuga (Rich.) } \\
\text { H.S.Irwin \& Barneby }\end{array}$ & Fabaceae & $\mathrm{P}$ & $\mathrm{Au}$ & Aut & 1.97 & 1.4 & 1.23 & 2.62 & 4.59 \\
\hline $\begin{array}{l}\text { Myrsine coriacea (Sw.) R.Br. ex } \\
\text { Roem.\& Schult. }\end{array}$ & Myrsinaceae & $\mathrm{P}$ & $\mathrm{Z}$ & $\mathrm{Al}$ & 1.97 & 2.12 & 0.45 & 2.57 & 4.53 \\
\hline $\begin{array}{l}\text { Nectandra megapotamica } \\
\text { (Spreng.) Mez }\end{array}$ & Lauraceae & NP & $\mathrm{Z}$ & Aut & 1.97 & 1.92 & 0.5 & 2.42 & 4.39 \\
\hline Mabea fistulifera Mart. & Euphorbiaceae & $\mathrm{P}$ & $\mathrm{Au}$ & Aut & 1.57 & 1.89 & 0.67 & 2.56 & 4.13 \\
\hline Trema micantha (L.) Blume & Cannabaceae & $\mathrm{P}$ & $\mathrm{Z}$ & Aut & 0.39 & 3.49 & 0.03 & 3.52 & 3.91 \\
\hline $\begin{array}{l}\text { Aspidosperma cylindrocarpon } \\
\text { Müll.Arg. }\end{array}$ & Apocynaceae & NP & An & Aut & 0.39 & 3.49 & 0.03 & 3.52 & 3.91 \\
\hline Cecropia pachystachya Trécul & Urticace & $\mathrm{P}$ & $\mathrm{Z}$ & Aut & 1.97 & 1.66 & 0.22 & 1.88 & 3.85 \\
\hline $\begin{array}{l}\text { Syagrus romanzoffiana (Cham.) } \\
\text { Glassman }\end{array}$ & Arecaceae & NP & $\mathrm{Z}$ & Aut & 0.79 & 2.97 & 0.06 & 3.02 & 3.81 \\
\hline Croton urucurana Baill. & Euphorbiaceae & $P$ & $\mathrm{Au}$ & Aut & 0.79 & 2.77 & 0.19 & 2.97 & 3.75 \\
\hline Tabernaemontana hystrix Steud. & Apocynaceae & $\mathrm{P}$ & $\mathrm{Z}$ & Aut & 1.97 & 1.21 & 0.5 & 1.71 & 3.68 \\
\hline Citharexylum myrianthum Cham. & Verbenaceae & $\mathrm{P}$ & $\mathrm{Z}$ & Aut & 2.36 & 0.8 & 0.31 & 1.11 & 3.47 \\
\hline Pterocarpus rohrii Vahl & Fabaceae & NP & An & Aut & 1.57 & 1.75 & 0.14 & 1.89 & 3.47 \\
\hline $\begin{array}{l}\text { Maclura tinctoria }(\text { L.) D.Don } \\
\text { ex Steud. }\end{array}$ & Moraceae & NP & $\mathrm{Z}$ & Aut & 1.57 & 1.73 & 0.11 & 1.84 & 3.42 \\
\hline Luehea divaricata Mart. \& Zucc. & Malvaceae & NP & An & Aut & 0.79 & 2.36 & 0.17 & 2.53 & 3.32 \\
\hline Cordia sp. & Boraginaceae & $\mathrm{NC}$ & $\mathrm{NC}$ & $\mathrm{NC}$ & 0.79 & 1.31 & 0.97 & 2.28 & 3.07 \\
\hline Erythroxylum campestre A.St.-Hil. & Erythroxylaceae & $\mathrm{P}$ & $\mathrm{Z}$ & $\mathrm{Al}$ & 0.39 & 2.62 & 0.03 & 2.65 & 3.04 \\
\hline
\end{tabular}


Table 1 - Cont...

Tabela 1 - Cont...

\begin{tabular}{|c|c|c|c|c|c|c|c|c|c|}
\hline Aspidosperma polyneuron Müll.Arg. & Apocynaceae & NP & An & Aut & 0.39 & 2.62 & 0.03 & 2.65 & 3.04 \\
\hline Xylopia aromatica (Lam.) Mart. & Annonaceae & NP & $\mathrm{Z}$ & Al & 1.57 & 1.33 & 0.11 & 1.44 & 3.01 \\
\hline $\begin{array}{l}\text { Handroanthus heptaphyllus } \\
\text { (Vell.) Mattos }\end{array}$ & Bignoniaceae & NP & An & Aut & 0.39 & 2.44 & 0.03 & 2.47 & 2.87 \\
\hline Zanthoxylum riedelianum Engl. & Rutaceae & NP & Z & Al & 0.79 & 1.68 & 0.08 & 1.77 & 2.55 \\
\hline Prunus myrtifolia (L.) Urb. & Rosaceae & NP & Z & Aut & 1.18 & 1.17 & 0.14 & 1.31 & 2.49 \\
\hline Colubrina glandulosa Pekins & Rhamnaceae & NP & $\mathrm{Z}$ & Aut & 1.18 & 1.08 & 0.14 & 1.22 & 2.40 \\
\hline $\begin{array}{l}\text { Schizolobium parahyba (Vell.) } \\
\text { Blake }\end{array}$ & Fabaceae & $\mathrm{P}$ & An & Aut & 1.18 & 1.09 & 0.08 & 1.18 & 2.36 \\
\hline $\begin{array}{l}\text { Eriobotrya japonica (Thunb.) } \\
\text { Lindl.* }\end{array}$ & Rosaceae & $\mathrm{E}$ & $\mathrm{Z}$ & Al & 0.79 & 1.3 & 0.22 & 1.53 & 2.32 \\
\hline $\begin{array}{l}\text { Handroanthus ochraceus } \\
\text { (Cham.) Mattos }\end{array}$ & Bignoniaceae & NP & An & Aut & 0.79 & 1.33 & 0.11 & 1.44 & 2.23 \\
\hline Coffea arabica L.* & Rubiaceae & $\mathrm{E}$ & Z & Al & 0.39 & 1.69 & 0.11 & 1.8 & 2.2 \\
\hline Machaerium sp. & Fabaceae & $\mathrm{NC}$ & $\mathrm{NC}$ & $\mathrm{NC}$ & 0.39 & 1.7 & 0.06 & 1.76 & 2.15 \\
\hline Melia azedarach L.* & Meliaceae & $\mathrm{E}$ & $\mathrm{Z}$ & Al & 0.79 & 1.3 & 0.06 & 1.36 & 2.14 \\
\hline Dictyoloma vandellianum A. Juss. & Rutaceae & $\mathrm{P}$ & An & Aut & 0.39 & 1.61 & 0.11 & 1.72 & 2.12 \\
\hline Lafoensia pacari A.St.-Hil. & Lythraceae & NP & An & Aut & 0.79 & 1.12 & 0.19 & 1.32 & 2.1 \\
\hline Myracrodruon urundeuva Allemão & Anacardiaceae & NP & $\mathrm{Au}$ & Aut & 0.79 & 1.14 & 0.14 & 1.28 & 2.06 \\
\hline Copaifera langsdorffii Desf. & Fabaceae & NP & $\mathrm{Z}$ & Aut & 0.39 & 1.21 & 0.14 & 1.35 & 1.74 \\
\hline $\begin{array}{l}\text { Zeyheria tuberculosa (Vell.) } \\
\text { Bureau ex Verl. }\end{array}$ & Bignoniaceae & NP & An & Aut & 0.39 & 1.26 & 0.03 & 1.28 & 1.68 \\
\hline Vitex sp. & Lamiaceae & $\mathrm{NC}$ & $\mathrm{NC}$ & Al & 0.39 & 1.24 & 0.03 & 1.27 & 1.66 \\
\hline Anadenanthera sp. & Fabaceae & $\mathrm{NC}$ & $\mathrm{NC}$ & $\mathrm{NC}$ & 0.39 & 1.05 & 0.03 & 1.08 & 1.47 \\
\hline $\begin{array}{l}\text { Handroanthus cf. serratifolius } \\
\text { (A.H.Gentry) S.Grose }\end{array}$ & Bignoniaceae & NP & An & Aut & 0.39 & 0.96 & 0.03 & 0.99 & 1.38 \\
\hline $\begin{array}{l}\text { Bastardiopsis densiflora } \\
\text { (Hook. \& Arn.) Hass1. }\end{array}$ & Malvaceae & $\mathrm{P}$ & $\mathrm{Au}$ & Aut & 0.39 & 0.89 & 0.03 & 0.92 & 1.31 \\
\hline $\begin{array}{l}\text { Pera glabrata (Schott) Poepp. } \\
\text { ex Baill. }\end{array}$ & Euphorbiaceae & $\mathrm{P}$ & Z & Al & 0.39 & 0.87 & 0.03 & 0.9 & 1.29 \\
\hline Ficus sp. & Moraceae & $\mathrm{NC}$ & $\mathrm{NC}$ & $\mathrm{NC}$ & 0.39 & 0.84 & 0.03 & 0.87 & 1.26 \\
\hline $\begin{array}{l}\text { Dendropanax cuneatus (DC.) } \\
\text { Decne. \& Planch. }\end{array}$ & Araliaceae & $\mathrm{P}$ & $\mathrm{Z}$ & Aut & 0.39 & 0.8 & 0.03 & 0.83 & 1.22 \\
\hline Gallesia integrifolia (Spreng.) Harms & Phytolaccaceae & NP & An & Aut & 0.39 & 0.73 & 0.03 & 0.76 & 1.15 \\
\hline Tabebuia roseoalba (Ridl.) Sandwith & Bignoniaceae & NP & An & Aut & 0.39 & 0.72 & 0.03 & 0.74 & 1.14 \\
\hline Handroanthus sp. & Bignoniaceae & $\mathrm{NC}$ & $\mathrm{NC}$ & $\mathrm{NC}$ & 0.39 & 0.7 & 0.03 & 0.73 & 1.12 \\
\hline Heliocarpus popayanensis Kunth & Malvaceae & $\mathrm{P}$ & An & Aut & 0.39 & 0.61 & 0.03 & 0.64 & 1.03 \\
\hline Allophylus L. & Sapindaceae & $\mathrm{NC}$ & $\mathrm{NC}$ & Al & 0.39 & 0.54 & 0.06 & 0.6 & 0.99 \\
\hline
\end{tabular}

*Exotic species were not classified according to successional group.

* Espécies exóticas não foram classificadas de acordo com o grupo sucessional.

We also found three species classified as "vulnerable" (Myracrodruon urundeuva) and as "near threatened" (Aspidosperma polyneuron and Copaifera langsdorffii), according Mamede et al. (2007).

\section{DISCUSSION}

The RPPN woody regenerating stratum was also larger than other reforestations with similar age done in São Paulo State, Brazil (SOUZA, 2000; MELO, 2004; DAMASCENO, 2005). We believe the high diversity found at RPPN must be associated to the high diversity of seedlings (100 species) used in this reforestation project. This diversity is much higher in comparison to Souza (2000) and Damasceno (2005) where it was used less than 45 species in their reforestation projects.

Where the secondary succession occurs naturally in Atlantic forest, a high diversity of species in the first decades is observed, and it has been increasing over the years (TABARELLI; MANTOVANI, 1999; ARZOLLA et al., 2010). Many aspects of structure, composition and ecological interactions in a secondary succession of tropical forest have been broadly studied, such as: diameter, height, biomass, density of specimens, species composition, specially richness and diversity

Revista Árvore, Viçosa-MG, v.40, n.2, p.209-218, 2016 
of species, because of their great importance in this process (SALDARRIAGA et al., 1988; GUARIGUATA; OSTERTAG, 2001; CHAZDON, 2003; CHAZDON et al., 2007; CHAZDON et al., 2010). When the degraded areas have resilience with remnants surrounding, it plays an indispensable role in forest recovery, promoting rapid increasing in species richness, tree density and aboveground biomass on a restored area (GUARIGUATA; OSTERTAG, 2001; CHAZDON, 2003).

On the other hand, in fragmented forest landscape, where the propagules are not abundant, a low diversity of tree plantations will not be sufficiently able to catalyze forest restoration (KANOWSKI et al., 2003; LARJAVAARA, 2008; RODRIGUES et al., 2011). The absence of fauna in these areas enhances the problem (DASILVA; TABARELLI, 2000; RODRIGUES etal., 2011). In this context, the high-diversity of native seedlings must create a feasible biologically restored forests, and to assist long-term biodiversity persistence at the landscape scale (RODRIGUES et al., 2011).

The process of recovery of the tropical forest on the initial colonization stages occurs with little number of species, in comparison to reforestation models (BUDOWSKI, 1965; GUARIGUATA; OSTERTAG, 2001; MELO; DURIGAN, 2007). According to Melo and Durigan (2007), about $70 \%$ of species from a restoration community was formed by species dispersed from remnants, after 15 years, in a seasonal semideciduous forest. Although RPPN has only nine years, new species have been already dispersed on the area, as verified by allochthonous species found. However, there are few nearby fragments that act as a source of seed.

The fauna is very important to the forest restoration process, because disperses propagules from remnants and contributes to the natural regeneration (MELO; DURIGAN, 2007;AQUINO; BARBOSA, 2009; SILVEIRA et al., 2011; TREVELIN et al., 2013). The zoochoric species planted on a reforestation in RPPN have been very important in attracting the fauna, which in return contributes to the dispersion of new species on the area. Trevelin et al. (2013) evaluated the dispersion capacity of the frugivorous bat at the same RPPN, and verified that the young reforestation can be used as feeding and resting habitat for this wildlife. Among 12 species consumed by eight species of bats, based on the study by Silveira et al. (2011) in RPPN, seven were present in the wood regenerating species composition: Dendropanax cuneatum, Cecropia pachystachya, Inga vera subsp. affinis, Copaifera langsdorfûi, Maclura tinctoria, Eugenia uniflora and Psidium guajava. The fauna dispersion and the presence of allochthonous species on the wood regenerating is an indicator that the ecological process is providing the arrival of new species in the reforestation, and providing the biodiversity recovery, which is essential to the sustainability of restored areas (RODRIGUES et al., 2009a).

Mantovani et al. (1989) had already related the influence of Cerrado sensu lato (Neotropical Savana) species in preserved fragments near RPPN. The presence of species from different biomes on reforestation, is an evidence of the ecotone zone, and it should always been considered in a reforestation project, such as was considered in RPPN.

The presence of some species classified in different levels of threat (Mamede et al. 2007), highlights the importance of the reserve. Threatened species were planted, in RPPN, and their presence in the wood regenerating reveal the reproductive success and its consequent dispersion on the RPPN, which is important for their conservation. Reforestations have maintained a trend in restoring functional aspects, especially riparian forests, over the function of the restoration and preservation of diversity (MELO; DURIGAN, 2007). Therefore, there is a great importance in the usage of regional, endemic and threatened species in restorations projects, as suggested by SMA 32/2014 guidelines (SÃO PAULO, 2014).

There was a slight difference in pioneer and nonpioneer species composition, but the number of pioneer specimens is much higher, as result of the high abundance of some species (Table 1). Pioneer species have faster growth, and are responsible for creating a favorable environment to non-pioneers species developing (WHITMORE, 1989; TABARELLI; MANTOVANI, 1999; GUARIGUATA; OSTERTAG, 2001). The early establishment of pioneer tree species is a critical aspect of rapid recovery. As observed in secondary succession, pioneer species establish abundantly in abandoned pastures and cultivated fields, but the particular species that colonize will depend on of some environmental aspects, such as: soil fertility, drainage, soil compaction, presence or absence of seed bank, and surrounding remnant vegetation (CHAZDON, 2003). 
The presence of exotic species, in the higher heights reveals its capacity of establishment in the future reforestation canopy (LETCHER; CHAZDON, 2009). Although Mimosa caesalpiniifolia is Brazilian native specie, it does not occur spontaneously in Atlantic forest; therefore, it is considered exotic specie in this biome, according to Moro et al. (2012) classification criterion. Tecoma stans is an exotic specie also found in the RPPN. These species has been used as ornamental in the cities, but it became invasive specie in Brazilian forest. Due to its anemochoric seeds, Tecoma stans can easily be dispersed by wind, growing in pasture and secondary forest, affecting the secondary succession (REIS et al., 2009). The presence of exotic species is a seriously problem in Brazilian reforestations (RODRIGUES et al. (2009a,b), and for full eradication of them inside and surrounding the reforestation areas is necessary to avoid the biological contamination.

\section{CONCLUSIONS}

We conclude that the use of high diversity of native seedlings in reforestation leads to high diversity of species in woody regeneration stratum after one decade of planting.

\section{ACKNOWLEDGMENTS}

We thank International Paper Brazil, especially Miguel Magela Diniz and João Machado, for the logistical support and authorizing the work in the restored forest, as well as São Paulo Botanical Institute and its program of post-graduation "Biodiversidade Vegetal e Meio Ambiente"; and "Conselho Nacional de Desenvolvimento Científico" (CNPq) for financial support. We thank the "Coordenação Especial de Restauração de Áreas Degradadas" (CERAD) members for their assistance. And we thank Eduardo Luís Martins Catharino too, for his consideration on the ecology of the species.

\section{REFERENCES}

APG III - Angiosperm Phylogeny Group III. An update of the Angiosperm Phylogeny Group classification for the orders and families of flowering plants. Botanical Journal of the Linnean Society, v.161, n.2, p.105-121, 2009 .

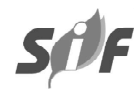

AQUINO, C.; BARBOSA, L.M. Classes sucessionais e síndromes de dispersão de espécies arbóreas e arbustivas existentes em vegetação ciliar remanescente (Conchal, SP), como subsídio para avaliar o potencial do fragmento como fonte de propágulos para enriquecimento de áreas revegetadas no rio Mogi-Guaçu, SP.

Revista Árvore, v.33, n.2, p.349-358, 2009.

ARONSON, J.; BRANCALION, P.H.S.; DURIGAN, G.; RODRIGUES, R.R.; ENGEL, V.L.; TABARELLI, M.; TOREZAN, J.M.D.; GANDOLFI, S.; MELO, A.C.G.; KAGEYAMA, P.Y.; MARQUES, M.C.M.; NAVE, A.G.; MARTINS, S.V.; GANDARA, F.B.; REIS, A.; BARBOSA, L.M.; SCARANO, F.R. What role should government regulation play in ecological restoration? Ongoing debate in São Paulo State, Brazil. Restoration Ecology, v.19, n.6, p.690-695, 2011.

ARZOLLA, F.A.R.D.P.; VILELA, F.E.S.P.; PAULA, G.C.R.; SHEPHERD, G.J. Regeneração natural em clareiras de origem antrópica na Serra da Cantareira, SP. Revista do Instituto Florestal, v.22, n.1, p.155-169, 2010.

BARBOSA, K.C.; PIZO, M.A. Seed rain and seed limitation in a planted gallery forest in Brazil. Restoration Ecology, v.14, n.4, p.504-515, 2006.

BRANCALION, P.H.S.; RODRIGUES, R.R.; GANDOLFI, S.; KAGEYAMA, P.Y.; NAVE, A.G.; GANDARA, F.B.; BARBOSA, L.M.; TABARELLI, $M$. Instrumentos legais podem contribuir para a restauração de florestas tropicais biodiversas. Revista Árvore, v.34, n.3, p.455-470, 2010.

BUDOWSKI, G. Distribution of tropical American rain forest species in the light of successional processes. Turrialba, v.15, n.1, p.40-42, 1965.

CALMON, M.; BRANCALION, P.H.S.; PAESE, A.; ARONSON, J.; CASTRO, P.; SILVA, S.C.; RODRIGUES, R.R. Emerging Threats and Opportunities for Large Scale Ecological Restoration in the Atlantic Forest of Brazil. Restoration Ecology, v.19, n.2, p.154-158, 2011.

CHAZDON, R.L. Tropical forest recovery: legacies of human impact and natural disturbances.

Perspectives in Plant Ecology,

Revista Árvore, Viçosa-MG, v.40, n.2, p.209-218, 2016 
Evolution and Systematics, v.6, n.1, p.51-71, 2003.

CHAZDON, R.L.; FINEGAN, B.; CAPERS, R.S.; SALGADO-NEGRET, B.; CASANOVES, F.; BOUKILI, V.; NORDEN, N. Composition and dynamics of functional groups of trees during tropical forest succession in Northeastern Costa Rica. Biotropica, v.42, n.1, p.31-40, 2010.

CHAZDON, R.L.; LETCHER, S.G.; BREUGEL M.; MARTÍNEZ-RAMOS M.; BONGERS, F.;

FINEGAN, B. Rates of change in tree communities of secondary Neotropical forests following major disturbances. Philosophical Transactions of the Royal Society B: Biological Sciences, v.362, n.1478, p.273289, 2007.

COLMANETTI, M.A.A. Estrutura da vegetação e características edáficas de um reflorestamento com espécies nativas. 2013. 165f. Dissertação (Mestrado em Biodiversidade Vegetal e Meio Ambiente) Instituto de Botânica de São Paulo, São Paulo, 2013.

COLMANETTI, M.A.A.; BARBOSA, L.M. Fitossociologia e estrutura do estrato arbóreo de um reflorestamento com espécies nativas em Mogi-Guaçu, SP, Brasil. Hoehnea, v.40, n.3, p.419-435, 2013.

COLMANETTI, M.A.A.; SHIRASUNA, R.T.; BARBOSA, L.M. Flora vascular não arbórea de um reflorestamento implantado com espécies nativas. Hoehnea, v.42, n.4, p.725-735, 2015.

DA SILVA, J.M.C.; TABARELLI, M. Tree species impoverishment and the future flora of the Atlantic forest of northeast Brazil. Nature, v.404, n.6773, p.72-74, 2000.

DAMASCENO, A.C.F. Macrofauna edáfica, regeneração natural de espécies arbóreas, lianas e epífitas em florestas em processo de restauração com diferentes idades no Pontal do Paranapanema. 2005. 108f. Dissertação (Mestrado em Recursos Florestais) - Escola Superior de Agricultura "Luiz de Queiroz" Universidade de São Paulo, Piracicaba, 2005.
DURIGAN, G.; ENGEL, V.L.; TOREZAN, J.M.; MELO, A.C.G.; MARQUES, M.C.M.; MARTINS, S.V.; REIS, A.; SCARANO, F.R. Normas jurídicas para a restauração ecológica: uma barreira a mais a dificultar o êxito das iniciativas? Revista Árvore, v.34, n.3, p.471-485, 2010.

GUARIGUATA, M.R.; OSTERTAG, R. Neotropical secondary forest succession: changes in structural and functional characteristics. Forest Ecology and Management, v. 148, n.1, p.185-206, 2001.

GUILHERME, F.A.G. Efeitos da cobertura de dossel na densidade e estatura de gramíneas e da regeneração natural de plantas lenhosas em mata de galeria, Brasília-DF. Cerne, v.6, n.1, p.60-66, 2000.

HAMMER, Ø.; HARPER, D.; RYAN, P. Past: Paleontological Statistics Software Package for education and data analysis. Paleontología Electrónica, v.4, p.1-9, 2001. URL: http:// palaeo-electronica. org/2001_1/past/issue1_01. html, 2001.

KANOWSKI, J. et al. Development of forest structure on cleared rainforest land in eastern Australia under different styles of reforestation. Forest Ecology and Management, v.183, n.1, p.265-280, 2003.

KÖPPEN, W. Climatologia: con un estudio de los climas de la tierra. México: Fondo de Cultura Econômica, 1948. 479p.

LARJAVAARA, M. A review on benefits and disadvantages of tree diversity. Open Forest Science Journal, v.2008, n.1, p.16-18, 2008.

LETCHER, S.G.; CHAZDON, R.L. Rapid recovery of biomass, species richness, and species composition in a forest chronosequence in northeastern Costa Rica. Biotropica, v.41, n.5, p.608-617, 2009.

MAGURRAN, A.E. Measuring biological diversity. Oxford: Blackwell Science Ltd, 2004. 256p.

MAMEDE, M.C.H.; SOUZA, V.C.; PRADO, J.; BARROS, F.; WANDERLEY, M.G.L.; RANDO, J.G. Livro vermelho das espécies vegetais 
ameaçadas de extinção no Estado de São Paulo. São Paulo: Imprensa Oficial, 2007.

MANDETTA, E.C.N. Avaliação florística e de aspectos da estrutura da comunidade de um reflorestamento com dois anos e meio de implantação no município de Mogi-Guaçu/SP. 2007. 155f. Dissertação (Mestrado em Biologia Vegetal) - Universidade Estadual Paulista, Rio Claro, 2007.

MANTOVANI, W.; ROSSI, L.; ROMANIUC NETO, S.; ASSAD-LUDEWINGS, I.Y.; WANDERLEY, M.G.; MELO, M.M.R.F.; TOLEDO, C.B. Estudo fitossociológico de áreas de mata ciliar em Mogi-Guaçu, SP, Brasil. In: SIMPÓSIO SOBRE MATA CILIAR, 1., 1989, Campinas, SP. Anais... Campinas: Fundação Cargill, 1989. p.235-267.

MELO, A.C.G.D. Reflorestamentos de restauração de matas ciliares: análise estrutural e método de monitoramento no médio Vale do Paranapanema (SP). 2004. $151 \mathrm{f}$. Dissertação (Mestrado em Ciências da Engenharia Ambiental). Universidade de São Paulo, São Carlos, 2004.

MELO, A.D.; DURIGAN, G. Evolução estrutural de reflorestamentos de restauração de matas ciliares no Médio Vale do Paranapanema.

Scientia Forestalis, v.73, p.101-111, 2007.

MORO, M.F.; SOUZA, V.C.; OLIVEIRA-FILHO, A.T; QUEIROZ, L.P.; FRAGA, C.N.; RODAL, M.J.N; ARAÚJO, F.S.; MARTINS, F.R. Alienígenas na sala: o que fazer com espécies exóticas em trabalhos de taxonomia, florística e fitossociologia? Acta Botanica Brasilica, v.26, p.991-999, 2012.

MUELLER-DOMBOIS, D.; ELLENBERG, H. Aims and methods of vegetation ecology. New York: John Wiley \& Sons, 1974. 547p.

MYERS, N; MITTERMEIER, R.A.; MITTERMEIER, C.G.; FONSECA, G.A.B.; KENT, J. Biodiversity hotspots for conservation priorities. Nature, v.403, p.853-858, 2000.

PIELOU, E.C. Ecological diversity. New York: Jonhon Willey, 1975. 165p.
REIS, A.S.; REIS, T.E.S.; REIS, L.C.; TASHIMA, H.; MORENO, R.M.; MAYER, C.M. Krigagem para análise de infestação do Tecoma stans. In: SIMPÓSIO DE GEOESTATÍSTICAAPLICADA EM CIÊNCIAS AGRÁRIAS, 2009, Botucatu.

Anais...Botucatu: 2009. p.1-5.

RIBEIRO, M.C.; METZGER, J.P.; MARTENSEN, A.C.; PONZONI, F.J.; HIROTA, M.M. The Brazilian Atlantic Forest: How much is left, and how is the remaining forest distributed? Implications for conservation. Biological conservation, v.142, n.6, p.1141-1153, 2009.

RODRIGUES, R.R.; BRANCALION, P.H.S.; ISERNHAGEN, I. (Org.) Pacto para a restauração ecológica da Mata Atlântica: referencial dos conceitos e ações de restauração florestal. São Paulo: Instituto BioAtlântica, 2009a. p.55-61.

RODRIGUES, R.R.; GANDOLFI, S.; NAVE, A.G.; ARONSON, J.; BARRETO, T.E.; VIDAL C.Y.; BRANCALION, P.H.S. Large-scale ecological restoration of high-diversity tropical forests in SE Brazil. Forest Ecology and Management, v.261, n.10, p.1605-1613, 2011.

RODRIGUES, R.R.; LIMA, R.A.F.; GANDOLFI, S.; NAVE, A.G. On the restoration of high diversity forests: 30 years of experience in the Brazilian Atlantic Forest. Biological conservation, v.142, n.6, p.1242-1251, 2009b.

SALDARRIAGA, J.G.; WEST, D.C.; THARP, M.L.; UHL, C. Long-term chronosequence of forest succession in the upper Rio Negro of Colombia and Venezuela. Journal of Ecology, v.76, p.938-958, 1988.

SAS Institute. SAS user's guide: statistics version 9.2. Cary: 2007.

SILVEIRA, M.; TREVELIN, L.; PORT-CARVALHO, M.; GODOI, S.; MANDETTA, E.N.; CRUZ-NETO, A.P. Frugivory by phyllostomid bats (Mammalia: Chiroptera) in a restored area in Southeast Brazil. Acta Oecologica, v.37, n.1, p.31-36, 2011.

SIMPSON, E.H. Measurement of diveristy. Nature, v. 163, p.688, 1949.

SOUZA, F. Estrutura e dinâmica do estrato arbóreo e da regeneração

Revista Árvore, Viçosa-MG, v.40, n.2, p.209-218, 2016

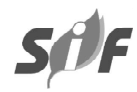


natural em áreas restauradas. 2000 . 78f. Dissertação (Mestrado em Recursos Florestais) - Escola Superior de Agricultura "Luiz de Queiroz" - Universidade de São Paulo, Piracicaba, 2000.

SÃO PAULO. Secretaria de Meio Ambiente do Estado de São Paulo. Resolução no 32 , de 03 de abril de 2014. Diário Oficial do Estado de São Paulo, São Paulo, 05/04/2014. Seção Meio Ambiente, 2014.

TABARELLI, M.; MANTOVANI, W. A regeneração de uma floresta tropical montana após corte e queima (São Paulo-Brasil). Revista Brasileira de Biologia, v.59, n.2, p.239-250, 1999.

TREVELIN, L.C.; SILVEIRA, M.; PORTCARVALHO, C.; HOMEM, D.H.; CRUZ-NETO, A.P. Use of space by frugivorous bats (Chiroptera: Phyllostomidae) in a restored Atlantic forest fragment in Brazil. Forest Ecology and Management, v.291, n.1, p.136-143, 2013.

WHITMORE, T. Canopy gaps and the two major groups of forest trees. Ecology, v.70, n.3, p.536$538,1989$. 